\title{
Policy, Legal, and Institutional Frameworks for PPP Implementation in Development Process: Stakeholders' Perspective
}

\author{
Teshome Tafesse Beyene \\ Ethiopian Civil Service University (ECSU), Addis Ababa, Ethiopia
}

\begin{abstract}
This study assessed the policy, legal, and institutional frameworks for public private partnership (PPP) implementation in development process based on the perspectives of stakeholders in Ethiopia. An exploratory sequential mixed method was employed. One hundred and twenty-one stakeholders were selected from public, private, existing PPPs, and development partners, Think Thank and civil society organizations (CSOs) were participated. The findings revealed that prevalence of specific legal framework for PPP, prevalence of PPP dedicated public agency, and government guarantee are the most important factors to be put in place to implement PPP in the development process of the country. An inclusion of PPP as part of the development policy, devising a specific legal framework and establishing an independent public agency for PPP is the suggestion forwarded by the stakeholders. The study recommends to incorporate PPP in the existing development policy as one of the development strategies, to devise PPP strategy of the country and specific legal framework of PPP, and to establish a federal PPP agency with the full mandate of undertaking PPP related issues under the Prime Minister's office.
\end{abstract}

Keywords: public, private, civil society, legal framework, institutional framework, public private partnership (PPP)

\section{Introduction}

Government is a traditional provider of public services and an operator of public service delivery institutions and development projects using resources from public sources, i.e., taxes and levy. However, the ever-increasing disparity between the capacity of the public sector to generate resources and the public demand for new facilities has forced governments to look for new funding methods and sources. Public private partnership (PPP) as a new funding method is an increasingly popular phenomenon and a global trend (Hodge, 2005).

PPP is a long-term contractual arrangement between a public-sector agency and a private-sector entrepreneur, whereby resources and risks are shared for the purpose of developing a public facility. For the public sector, the principal aim of a PPP is to achieve value for money (Akintoye, Beck, \& Hardcastle, 2003). In relation to this, Alinaitwe and Robert (2013) elaborated that the public sector can secure value for money in the public service delivery, while ensuring that the PPP partnering private-sector entities meet their contractual obligations properly and efficiently. As a consequence, many countries are now contemplating PPP as an

Teshome Tafesse Beyene, Ph.D., assistant professor, Ethiopian Civil Service University (ECSU), Addis Ababa, Ethiopia.

Correspondence concerning this article should be addressed to Teshome Tafesse, P.O. Box: 22811, Code 1000, Addis Ababa, Ethiopia. E-mail: teshometafesse@gmail.com. 
arrangement between public and private sectors to finance, design, build, operate, and maintain public infrastructure, community facilities, and related development projects.

Though the potential advantage of PPPs in public service delivery and development process is well understood by most public policy makers and professionals around the globe, the extent in countries around the world in general and developing countries in particular is quite slow (Teshome, 2014a). Perhaps being unaware of some of the factors may preclude the enablers of the system from creating conducive environment for PPP implementation. Particularly developing countries which are striving hard to alleviate poverty and bring about development should effectively mobilize their resources and use their capacities for the success of their development goals. In light of this, Ethiopia, as a developing country striving hard to develop, should work hard to mobilize its available capacities from all sectors to keep forward its development targets. PPP is one of the best potential mechanisms to mobilize resources (be it of public, private, or civil society) in the form of collective action towards development and efficient public service delivery (Teshome, 2014a).

Hence, in line with this argument, it is imperative to study what specific factors affect adoption of PPP in any country planning to adopt PPP for its development. Assessing conditions required for PPP adoption with its legal and institutional environment are so important to start the new PPP arrangement. In view of this, this study takes up the task of assessing factors attracting implementation of PPP in development process of Ethiopia. Moreover, the prevalent condition for PPP including legal and institutional framework was studied. The study was mainly based on the stakeholders' perspectives. The researcher tried to associate and compare the summary perspective of stakeholders with the related best practices and empirical study findings done in PPP area somewhere around the globe. The study subjects were requested to share their hands on experience and knowledge regarding what conditions or factors are needed, so as PPP could operate, involve, and expand in Ethiopian development process. To keep the validity and reliability of the study, the researcher opted to use study tools employed by other scholars in PPP studies done somewhere else.

Studies by Li, Akintoye, Edwards, and Hardcastle (2005) and Cheung, Chan, and Kajewski (2009) tried to investigate the attractive factors for adopting PPP in their respective study area. The study of Li et al. (2005) revealed that the top three attractive factors were "transferring of risk to private sector", "solving the problem of public sector budget constraints", and "non-recourse or limited recourse public funding". The same study examined the differences between the public and private sectors respondents' perceptions on the importance of the attractive factors and reported that there are no significant differences in perception except for a few factors that are not among the top three attractive factors (Ismail, 2013).

A similar study done by Cheung et al. (2009) reported that the top three attractive factors for PPP in Hong Kong include "providing an integrated solution for public services", "facilitating creative and innovative approaches", and "solving the problem of public sector budget restraint". The top three attractive PPP factors for Australian respondents were "providing an integrated solution for public services", "facilitating creative and innovative approaches", and "saving time in delivering the project". The findings of the above studies reveal that factors perceived by respondents from different countries are not the same. This implies that factors attracting adoption of PPP may differ on the basis of the specific objective condition of the study area or country.

Therefore, the unique characteristics of PPP in each country influence the PPP attractiveness in the country (Ismail, 2013). Because of this, the case in Ethiopia can be expected to be different, not only because of the unique characteristics of the prevalent PPPs, but also because of the undeveloped conditions for PPP (Teshome, 2014b). 


\section{PPP in Ethiopian Policy and Legislative Documents}

The review of Federal Democratic Republic of Ethiopia's (FDRE) policy and national development documents reveals that partnership is one of the sought strategies of development. There are many legal and policy documents mentioning the significance of partnership between the public and private sector in the Ethiopian development process. The development policy document for rural development issued in 1994 acknowledged the significance of creating an integration or partnership between farmers and potential private investors in agricultural sector, particularly in securing and expanding markets for agricultural products. It was clearly stated in the policy document as: “... all sorts of efforts shall be done to find private companies with high level of experience in agricultural development and attract them to come and work with farmers in partnership ...”(Ministry of Information [MOI], 1994a, p. 211).

It further elaborates that this partnership can be in the form of "a contractual agreement between farmers and the private investing companies", as it is widely known as "out growers' agreement" (MOI, 1994a, p. 211). Knowing the critical importance of creating such partnership for the success of the agricultural and rural development, the policy document prescribes that "the government should work hard to put in place all preconditions or enable environment to establish and expand the out grower system of partnership" between farmers and the private investors (MOI, 1994a, p. 215).

Ethiopia's industrial development strategy of 1994 elaborates the importance of the public and private partnership for the success of the policy. It particularly states that "the government shall work with private investors in a more collaborated manner and partnership so as the envisaged policy objective could be attained" (MOI, 1994b, p. 64). It is also boldly stated in the Plan for Accelerated and Sustained Development to End Poverty (PASDEP) document that, as the private and civil society sectors have grown, diversified, and expanded their program activities and areas of public engagement, they have been gaining an increased support and recognition from the public side (Ministry of Finance and Economic Development [MOFED], 2006). The government itself has gradually opened avenues for private and civil society sectors involvement in many areas. A PASDEP, the government's development plan for the year from 2005 to 2010, recognized the strong role that non-governmental organizations (NGOs) have been playing and will continue to play in the effort to overcome poverty and meet the Millennium Development Goals (MDGs). This is more strengthened by Dessalegn, Akalewold, and Yoseph (2010), who asserted that the Ethiopian government will find it difficult to meet the MDGs, especially in the nutrition, health, education, and water sectors, without the active intervention of the voluntary sector (civil society).

The Growth and Transformation Plan (GTP) document explains that efforts shall be done to enable the private sector to be the engine of growth and the primary source of investment. It also makes clear that domestic and international participants will be encouraged and an "active partnership between the public and private sectors will be promoted" (MOFED, 2010, p. 144). As it is stated in GTP documents, the planned activity to promote growth and development embraces a number of critical factors for Ethiopia, among which the "private and public partnership is one of these factors" (MOFED, 2010, p. 224).

The document clearly describes to "provide better access to services (water, power, irrigation, roads, and telecommunication) through more efficient utilization of existing infrastructure and building new capacity and to promote PPPs in infrastructure development for industrial development and speeding up implementation of industrial zones" (MOFED, 2010, p. 157). 
Moreover, the country strategy paper for the years from 2011 to 2015 states that the private sector is expected to play a major role in GTP implementation. However, clearer strategies for crowding in private investment need to be articulated, particularly in the context of the current weaknesses in the financial sector and the business environment (African Development Bank, 2011).

Hence, one can easily understand from this that the Ethiopian government is well aware of the benefit of involving the private sector and civil society in the form of partnership in the process of development of the country. However, issues like the importance of dedicated PPP policy, legal, and institutional framework, what favorable sectors or areas of investment for partnership are there, and what is the potential of PPP in the context of Ethiopian development process, remain unclear.

Hence, this study assesses factors attracting the implementation of PPP in Ethiopia's development process, appropriate policy, legal, and institutional frameworks for PPP implementation in Ethiopia on the basis of the stakeholders' perspectives. The methodology and theoretical framework employed in this study are briefly presented below.

\section{Methodology and Theoretical Framework}

An exploratory sequential mixed method research design was employed (Hesse-Bibe, 2010). The stakeholders' perspectives about the factors attracting implementation of PPP were solicited by using a questionnaire survey. The researcher used some fitting factors stated in the questionnaire template designed by Cheung et al. (2009). The researcher believes that using the available list of factors was advisable compared to developing a new list of factors from scratch. As it is described by Ismail (2013), these are recognized by the sector and global scientific community as several articles using the same list of attractive factors have been published in reputable refereed scientific journals. To this end, list of factors used to measure stakeholders' perspective in this study is depicted in Table 1 below. To identify appropriate policy, legal, and institutional framework of PPP, qualitative approach was used. The qualitative data were collected using document review, interview, and open-ended questionnaire survey.

Table 1

List of Factors Attracting Adoption of PPP in Public Service Delivery and Development

\begin{tabular}{|l|l|l|}
\hline & Factors & Supporting literature \\
\hline 1 & Government support in providing guarantee & Cheung et al. (2009) \\
\hline 2 & Government support in providing loan & Cheung et al. (2009) \\
\hline 3 & Tax exemption or reduction & Cheung et al. (2009) \\
\hline 4 & Prevalence of PPP dedicated public agency & Qiao, Wang, Tiong, and Chan (2001); Yescombe (2007) \\
\hline 5 & Prevalence of PPP specific legal framework & Tiong (1996) \\
\hline 6 & Government's willingness to share risks & Qiao et al. (2001) \\
\hline
\end{tabular}

\section{PPP As Part of Development Policy}

PPP is emerging as a new development arrangement. In this regard, the dominant argument asserts that PPP maximizes benefits for development through collaboration and enhances efficiency (Bringkerhoff, 2001). Thus, PPP can be conceived as a very important method of promoting development and a tool for development (Binza, 2009).

Urio (2010) explained the importance of integrating of PPP into the development policy of developing countries. He further elaborated that the major goal of integrating PPP in the development strategy is to build a 
society that improves the attainment of the four values, namely: efficiency, equity, sustainability, and security. That is to mean, "an economy developing with a level of efficiency compatible with a sustainable pace, human activities (both private and public) organized and coordinated in a way that preserves the environment and more particularly scarce and non-renewable natural resources, organized in a way that realizes a balanced society with a reasonable, acceptable, and improving level of equity and security" (Urio, 2010, p. 52). There are some conditions expected to be fulfilled, so that PPP could be taken as a part of development strategy of a given country.

Accordingly, these conditions can be defined in three interrelated levels: strategic, contextual, and operational, each of them comprising a set of conditions or factors susceptible to having an impact on PPP (Urio, 2010). But in reality, these three levels are not perfectly separated (not entirely mutually exclusive). However, the author describes that the importance of dividing the three factors into manageable components is in view of making the analysis simple and clear, whereas, they are in fact imbedded into a single reality. Figure 1 summarizes the divided components of factors affecting the adoption and implementation of PPP.

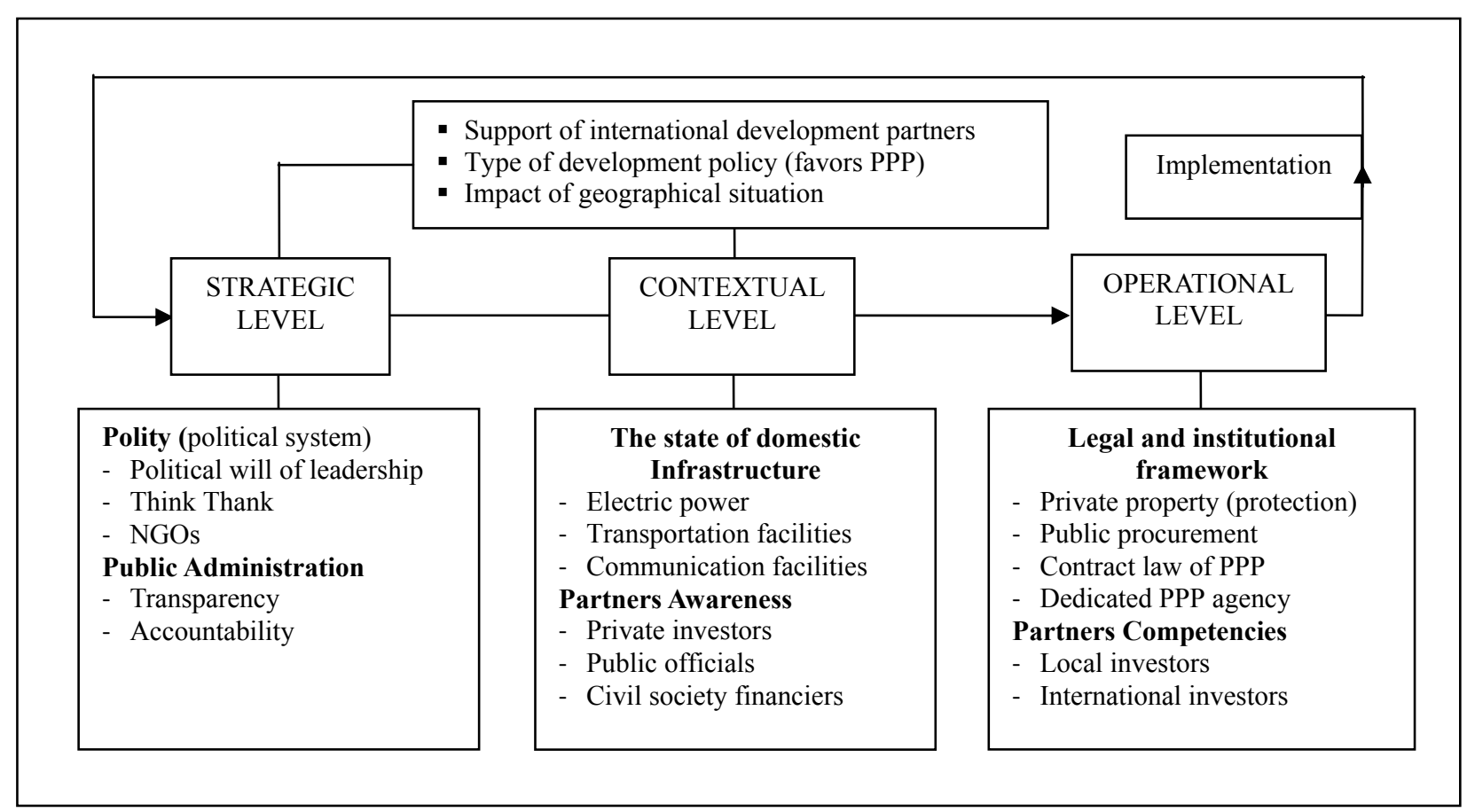

Figure 1. Three levels of conditions for PPP adoption as part of the development strategy. Source: Urio (2010).

As it can grasp from the Figure 1, the strategic level conditions comprise two major components: the polity and public administration. The polity comprises the political will of the leadership, Think Thank, and NGOs. These are listed under polity, because of their expected access to the political decision-making process. Transparency and accountability are important factors under public administration.

The contextual level incorporates the conditions within which the strategy is implemented. The following contextual elements are considered: the state of the development policy, availability and provision of infrastructures (electric city, transport, and communication facilities), the awareness of partners (private, public, and civil society) about PPP, impact or support of international development partners, and favorability in terms of geographical location and natural resource. 
The operational level includes the legal and Institutional framework, i.e., the rules governing the economy, private property, public procurement, contract law (and more specifically rules governing PPP), as well as the prevalence of PPP dedicated institution. Then, the competencies of partners to engage themselves in PPP contracts in terms of asset possession, financial capacity, legitimacy to secure loan, skills, and knowledge are factors considered in this level.

\section{Findings and Discussion}

\section{Sample and Data Collection Procedures}

An empirical cross sectional survey was conducted from January 2014 to March 2014 to analyze the major factors attracting PPP implementation in public service delivery and development projects in Ethiopia.

In this study, the target survey respondents included individuals from the public, private, and civil society sectors, and also development partner institutions, Think Thank, and available PPP institutions. The survey respondents were requested to rate their degree of agreement against each of the identified factors attracting the private sector partners to engage in PPP, according to a five-point Likert scale $(1=$ least important, $2=$ less important, 3 = important, $4=$ more important, and $5=$ most important).

Target respondents were selected using snowball sampling technique based on their direct hands-on involvement in PPP related issues and their willingness to participate in the survey. List of public, private, civil society, development partners, Think Thank, and PPP institutions, was created by considering potential, direct, or indirect involvement in issues related to PPP implementation in Ethiopian context. Then, a kind of quota sample was assigned to each institution to select individual practitioners or professionals to participate in the survey.

\section{Response Rate and Demographic Background of Respondents}

A total of 127 survey questionnaires were distributed to target respondents who are working in different public, private, civil societies, development partner, Think Thank, and PPP institutions. A total of 121 completed questionnaires were returned representing a high response rate of $95 \%$.

As it is shown in Table 2 below, among the 121 respondents, $41(32 \%)$ engaged in the private sector, 39 (31\%) in public sector, $12(9 \%)$ in the civil society sector, and $13(10 \%)$ in PPP. The remaining $10(8 \%)$ and six $(5 \%)$ were from the development partners and Think Thank institutions, respectively. The majority of the respondents were from the private and public sectors representing $80(63 \%)$ of the whole sample stratum.

Table 2

Response Rate of the Questionnaire

\begin{tabular}{|c|c|c|c|c|c|c|c|}
\hline \multirow{3}{*}{ Sector } & \multirow{2}{*}{\multicolumn{3}{|c|}{ Distributed }} & \multicolumn{3}{|c|}{ Returned } & \multirow{3}{*}{$\begin{array}{l}\text { Response } \\
\text {-Rate \% }\end{array}$} \\
\hline & & & & \multicolumn{3}{|c|}{ Sex } & \\
\hline & Female & Male & Total & Female & Male & Total & \\
\hline Civil society & 3 & 9 & 12 & 3 & 9 & 12 & 9.4 \\
\hline Development partners & 2 & 8 & 10 & 2 & 8 & 10 & 7.8 \\
\hline PPP & 4 & 9 & 13 & 4 & 9 & 13 & 10.2 \\
\hline Private sector & 12 & 31 & 43 & 12 & 29 & 41 & 32.3 \\
\hline Public sector & 11 & 32 & 43 & 11 & 28 & 39 & 30.7 \\
\hline Think Thank & 1 & 5 & 6 & 1 & 5 & 6 & 4.7 \\
\hline Total & 33 & 94 & 127 & 33 & 88 & 121 & 95.3 \\
\hline
\end{tabular}

Source: Survey output. 
As it is depicted in Table 3, the survey respondents comprised well-educated, experienced, and matured practitioners from five sectors with direct or indirect influence on PPP implementation, for instance, 63 (52\%) and $35(30 \%)$ of them are MA and BA degree holders, respectively. This constituted about $98(82 \%)$ of the total sample. The remaining four (3\%) and $19(16 \%)$ are $\mathrm{Ph} . \mathrm{D}$. and diploma holders, respectively. With regard to their age, $108(89 \%)$ are between 31-50 years of age, making the sample stratum dominated by matured people. As shown in Table 4, 68 (56\%) and 53 (44\%) of the respondents possessed more than 11 years and five years of work experience, respectively.

Table 3

Survey Respondents by Level of Education and Age Category

\begin{tabular}{lrrrrrrrrr}
\hline \multirow{2}{*}{ Sector } & \multicolumn{9}{c}{ Level of education } \\
\cline { 2 - 10 } & BA & DIP & MA & PhD & Total & Category & Female & Male & Total \\
\hline Civil society & 4 & 1 & 7 & 1 & 12 & $18-30$ & 3 & 5 & 8 \\
Dev. partners & 3 & 0 & 6 & 1 & 10 & $31-40$ & 18 & 30 & 48 \\
PPP & 2 & 4 & 7 & 0 & 13 & $41-50$ & 11 & 49 & 60 \\
Private sector & 13 & 7 & 21 & 0 & 41 & $>50$ & 1 & 4 & 5 \\
Public sector & 11 & 7 & 18 & 0 & 39 & Total & 33 & 88 & 121 \\
Think Thank & 0 & 0 & 4 & 2 & 6 & & & & \\
Total & 35 & 19 & 63 & 4 & 121 & & & & \\
\hline
\end{tabular}

Table 4

Factors Attracting PPP Implementation in Public Service Delivery and Development Projects

\begin{tabular}{lllllll}
\hline Variables & Obs & Mean & Std. Dev. & R & Min & Max \\
\hline Existence of specific PPP law & 121 & 4.818182 & 0.447214 & 1 & 3 & 5 \\
Existence of PPP dedicated public agency & 121 & 4.636364 & 0.483046 & 2 & 4 & 5 \\
Government guarantee & 121 & 4.404959 & 0.996481 & 3 & 2 & 5 \\
Tax exemption or reduction & 121 & 4.371901 & 0.720327 & 4 & 2 & 5 \\
Government provision of loan & 121 & 4.22314 & 0.73584 & 5 & 2 & 5 \\
Government willingness to share risk & 121 & 4.190083 & 0.767182 & 6 & 3 & 5 \\
\hline
\end{tabular}

Source: Survey output.

\section{Factors for Implementation of PPP in Development Stakeholders Perspective}

Table 4 illustrates the mean scores and the rank of the relative importance for each of the six factors based on the rating of all survey respondents. The result shows that the six factors were well perceived by all respondents to be either "more important" or "most important", because the mean scores for the factors range from 4.2 to 4.8 .

Moreover, the mean score rank result of all respondents indicates that three factors found to be most important in their ascending order of importance. These are "existence of specific PPP law" (MS = 4.8), "existence of PPP dedicated public agency" (MS = 4.6), and "government guarantee" (MS = 4.4).

The prevalence of specific legal framework for PPP is perceived by respondents as the basic and most important factor to implement PPP in public service delivery and development projects. Furthermore, the Stata software summary statistics shows that $84 \%$ of respondents expressed their perception by rating as "strongly agree", i.e., most important. When the rating of respondents from different sectors separately is seen, $85 \%$ of the private sector respondent and $77 \%$ of public sector respondents rated as "strongly agree". Interestingly enough, $100 \%$ of the respondents from the existing PPP rated the relative importance of PPP specific legal 
framework as "strongly agree". Moreover, $83 \%$ of civil society respondents rated the prevalence of legal framework as most important factor for PPP implementation as "strongly agree". This finding clearly indicates that PPP stakeholders in Ethiopia strongly believe that the federal government of Ethiopia has to devise a specific legal framework for PPP as a prerequisite, so that potential private and civil society partners would freely involve or engage in public service delivery and development oriented projects with government under PPP arrangement.

The second most important factor for PPP implementation in Ethiopian, as perceived by most respondents was "the existence of PPP dedicated public agency". This factor seems vital in a sense that a mere existence of PPP specific legal framework, may not serve the purpose, without owning institution to implement the provision stipulated in it. Put differently, the legal framework with its supporting rules and regulations needs to be owned by public agency with a full mandate to run and execute, according to norms and provisions stipulated in it. Unless an institutional arrangement is put in place, the mere existence of rules and regulations may not serve the purpose.

This finding supports the recommendation of Jamali (2004) suggesting that while PPP can bring added value to the partners, a sound legal and regulatory framework and complete transparency are essential elements. Also important is the presence of strong structure at the level of central administration to steer and guide policy implementation.

\section{Differences in the Perceptions of the Public and Private Sectors' Respondents on the Importance of Attractive Factors}

Based on the mean score rankings, the results of the public and private sector respondents on the perceived importance of each factor are almost similar except for differences in three factors. Table 5 shows that all factors were perceived to be more important by the private sector respondents than those by the public sector respondents. In this sense, in Ethiopia, PPP seems the main choice of the private sector to be involved in development projects in collaboration with government and in order to enhance its role in the process of overall development of the country.

Table 5

Summary of the Independent T-test Results for Attractive Factors

\begin{tabular}{lllllc}
\hline \multirow{2}{*}{ Attractive factors } & \multicolumn{3}{c}{ Mean } & \multicolumn{3}{c}{$T$-test } \\
\cline { 2 - 6 } & Private & Public & Diff. & $t$ & Sign. \\
\hline Government support in providing guarantee & 4.414634 & 4.384615 & 0.300188 & 0.1349 & 0.8930 \\
Government support in providing loan & 4.317073 & 4.051282 & 2.657911 & 1.5345 & $0.1290^{*}$ \\
Tax exemption or reduction & 4.512195 & 4.358974 & 1.532208 & 0.9203 & $0.3603^{*}$ \\
Prevalence of PPP dedicated public agency & 4.487805 & 4.487179 & 0.006254 & 0.0053 & 0.9958 \\
Prevalence of PPP specific legal framework & 4.682927 & 4.512821 & 1.701063 & 1.0055 & $0.3178^{*}$ \\
Government's willingness to share risks & 4.609756 & 4.512821 & 0.969356 & 0.6424 & 0.5225 \\
\hline
\end{tabular}

Note. * significant at 0.05 .

On the bases of the results illustrated in Table 5, it is prudent to conclude that there is a significant difference in the perception of the public and private respondents in three factors, namely: government support in providing loan, tax exemption or reduction, and prevalence of PPP specific legal framework. The data in Table 5 shows a statistically significant difference at $5 \%$ significance level. 
The private sector respondents perceived the attractive factor: The prevalence of PPP specific legal framework is significantly more important compared to the public sector respondents. This may be because the private sector considers it critical to gain confidence in PPP implementation process, such as negotiation, contract, and execution. Similarly, for the other two factors: tax exemption or reduction and government support in providing loan, the private sector respondents perceived them as significantly more important compared to public sector respondents. The private sector respondents believed that the issue of tax exemption and provision of loan services was among the most important factors motivating or attracting private partners' engagement in PPP.

The findings of Cheung et al. (2009) also indicate the prevalence of significant difference between the perceptions of respondents in Hong Kong and Australia. Their comparative study did not consider public and private sectors separately but overall respondents on the basis of their homelands. Similar, results are reported by Ismail (2013) on the presence of significant differences between the perceptions of private and public sector respondents in Malaysia. The latter study further reported that public sector respondents perceived the factors as more important than the private sector respondents (Ismail, 2013). In contrast, the findings of this study imply that the private sector respondents in Ethiopia perceived the factors as more important than the public sector respondents. The private sector respondents in Ethiopia perceived the attracting factors of PPP similar to that of the UK respondents ( $\mathrm{Li}$ et al., 2005).

\section{Policy, Legal, and Institutional Frameworks for PPP Implementation}

Conditions for PPP adoption. An assessment of conditions for PPP adoption and implementation in Ethiopia has been carried out using study variables recommended by Urio (2010). These are classified into three levels: strategic, contextual, and operational levels of conditions. Each of these comprises a set of factors having an impact on prevalence of PPP. Respondents were asked to indicate their opinion about the prevalence of conditions by choosing "yes", "no", or "do not know" options for each factor listed under the three major levels of conditions. Moreover, respondents were given the chance to express their point of view freely in the space provided in the questionnaire. In addition, relevant documents were assessed and interview data was used to support the findings, as it deemed necessary for some particular factors.

In summary from the strategic level conditions, the prevalence of political will among the polity was confirmed by both survey respondents and key interviewees. From the contextual level conditions, the country's geographic location is believed to be suitable for PPP expansion and development. The infrastructural development and expansion trend in the country, particularly the ongoing hydroelectric dam construction, railways, and road construction for transportation and telecom expansion for communication facilities can together be conducive contextual conditions for PPP expansion in Ethiopia.

The prevalence of constitutional protection for the right to possess private property is notable operational level condition prevalent in Ethiopia. The asset and financial capacity of local private sector investors as perceived by respondents also shows the confidence in the availability of capable investors among potential PPP partners in Ethiopia.

Legal framework of PPP. In order to assess the existing legal framework specific to PPP application in Ethiopia, the researcher conducted document review, open-ended questionnaire survey, and interviews. Specific documents reviewed for this question were: Public Enterprises Proclamation (No. 25/1992), Privatization of Public Enterprises Amendment Proclamation (182/1999), Investment Proclamation (No 
280/2002), Public Enterprises Supervising Agency Establishment Proclamation (No.412/2004), Procurement and Property Administration Proclamation (No. 649/2009), Investment Proclamation (No. 769/2012), and a journal article, Revisiting Company Law With the Advent of Ethiopian Commodity Exchange.

The relevant document review conducted in view of detecting the presence of specific legal framework for PPP reveals that the country lacks special legal instruments for PPP. The law of the land that governs business companies and associations, i.e., Commercial Code of Ethiopia of 1960 used the term "partnership" in its definition of business organization. According to the Commercial Code (article 210(1)), business organization is any association arising out of a partnership agreement. Though the use of the word "partnership" in the definition of business organization is likely to include PPP in the category of business organizations, the very definition of partnership agreement in the same code does not mention who the partners may be nor if one of the partners could be the government or public. The Commercial Code simply defines partnership agreement as a contract whereby two or more persons, who intend to join together, cooperate, and undertake to bring together contributions for the purpose of carrying out activities of an economic nature... Apart from defining business organization and partnership agreement in association with it, the code does not mention about PPP as one form of business organization.

According to article 2(1) of Public Enterprises Proclamation (No. 25/1992), public enterprises are companies established by law, where business organizations are registered companies that are established by a memorandum of association. Here, ambiguity is seen in the legal system - how PPP as a business entity could be established. In line with this point, article 2(3) of Privatization and Public Enterprises Supervising Agency Establishment Proclamation (No.412/2004) defines a share company as a company partially owned by the state and this definition replaces the total ownership provision stated in Proclamation (No. 146/1998) and Proclamation (No. 277/2002) and introduces the possibility of joint ventures with the government.

Here, some kinds of PPP arrangement envisaged in the process of privatization can be seen. Later on, this point is clearly elaborated in the Ethiopian Federal Government Procurement and Property Administration Proclamation (No. 649/2009). The term PPP is defined perhaps for the first time in the legal documents of Ethiopia as: Public private partnership means investment through private sector participation by a contractual arrangement between a public body and a private sector enterprise, as the concessionaire, in which the concessionaire undertakes to perform, any construction project, or service; or lease concession assumes substantial financial, technical, and operational risks in connection with the performance of a public function or use of government property; and receives consideration for performing a public function or utilizing government property, by way of fees from any public funds, user levies collected by the concessionaire from users or customers for a service provided by it, or a combination of such consideration (Federal Democratic Republic of Ethiopia [FDRE], 2009).

Even though, the term PPP is clearly defined in the law text, how it could be implemented in the public procurement process is not mentioned. The law empowers the minster of MOFED to issue rules and directives of PPP formation and implementation. Accordingly, this is stipulated as that the minister may issue directive prescribing the rules governing the formation of PPP and the modes of implementation of such partnership (FDRE, 2009).

Furthermore, the Investment Proclamation (No 769/2012) confers the power of decision to approve any proposal submitted by any private investor intending to engage with government in article 6(9) of the proclamation. It is described as: The privatization and public enterprises supervising agency shall receive 
investment proposals submitted by any private investor intending to invest jointly with the government; it shall submit same to the ministry of industry for decision and upon approval, designate a public enterprise to invest as partner in the joint investment (FDRE, 2012).

This clearly implies that the level of development achieved in the country is demanding new form of business structure one of which government is supposed to participate as a partner. However, there is a strong interest for PPP adoption, the existing system of rules and regulation seems inadequate to attract, mobilize, and implement PPP arrangement in the development of the country. The Commercial Code of the country is not modified or updated to accommodate such developments. One of the very evidence for this point is that, the initiation of founding Exchange Commodity Exchange (ECX) with its unique characteristics has brought a challenge in the legal system.

The respondents were asked to indicate their opinion about the prevalence of PPP dedicated policy in Ethiopia. The majority of respondents 59 (49\%) reported that they do not know whether the existing development policy is suitable for PPP implementation or not. The qualitative data synthesized from interviews indicate that the existing policy is highly suitable for private sector development, but not for PPP involvement in development. The fact that PPP is not incorporated in the development policy as a component, in the form of development strategy, shows that the existing development policy is not suitable as desired. On one hand, 87 (72\%) respondents reported that PPP is not incorporated in the development policy as development strategy. This response is supported by data obtained from the interviews and document review.

On the other hand, 91 (75\%) of the respondents believe that there is no specific law or regulation of PPP that could attract investors to engage in PPP projects. This finding is in harmony with the data obtained from interviews and also the document review done in light of the purpose of this study.

Institutional framework of PPP. In order to assess the existing institutional framework of PPP in Ethiopia, document review, open-ended questionnaire survey and interview were conducted. Specific documents reviewed for this question were: Privatization of Public Enterprises Amendment Proclamation (182/1999), Investment Proclamation (No 280/2002), Public Enterprise Supervising Authority Establishment proclamation (No 412/2004), Ethiopian Federal Government Procurement and Property Administration Proclamation (No. 649/2009), and Investment Proclamation (No. 769/2012). The review of legal texts detects conflicting provisions regarding government bodies in charge of PPP related issues. Article 34 of Procurement and Property Administration Proclamation (No. 649/2009) confers the power to the minster of MOFED to issue rules and directives of PPP formation and implementation. Whereas Investment Proclamation (No 769/2012) of article 6 (9) confers the power of decision to approve any proposal submitted by any private investor intending to engage with government to Ministry of Industry. Therefore, review of the relevant documents shows that there is no PPP dedicated public agency or enterprise with a mandate to regulate, manage, and oversee the implementation of PPP in Ethiopia.

Interviewees from the private and civil society sectors mentioned that the country lacks an independent and empowered public agency to run PPP issues in Ethiopia. This gap further exacerbated mistrust among the potential partners from the private and civil society sectors and the government. Had the agency been available in the public administration system, it would have pursued developmental promotional activities to bring about potential partners from all sectors into development agenda, which would have in turn built strong confidence and trust among all partners. 
Whereas interviewees from the public sector argue that there is an enough institutional arrangement to accommodate potential partnership projects. Therefore, they say, having a special agency for PPP may not be feasible. They insist that the attention of the public sector should be on building the capacity of private investors in financial, technical, and ethical terms, so that they can have adequate capacity to work in mega development projects in collaboration with the government in PPP arrangement. They believe that the current capacity of the private sector by and large is not enough to work with the government in big development projects. The interviewee from the private sector admitting the infancy of the private sector argued that the private sector capacity is now growing to the level of contributing to the ongoing development of the country comparatively more than the public sector itself. In the recent past, the private and public sectors were both incapable due to the past socialist oriented command economy. Hence, devising mechanisms such as specific regulations and institutional frameworks for PPP may help to build the capacity of both sectors.

\section{Suggested Policy, Legal, and Institutional Framework}

Type of policy suggested. According to data displayed in Table 6, 95 (79\%) respondents suggested a type of policy that accommodates PPP as part of the development strategy. This suggestion is supported by most of the interviews from all sectors. This would also provide a legitimate opportunity for all sectors to shoulder and execute societal and developmental responsibilities with full confidence. Urio (2010) suggested this type of policy as the best option to utilize the potential of the private sector particularly for developing countries.

Table 6

Summary of Stakeholders' Suggestion on Type of Policy, Legal, and Institutional Framework of PPP for Ethiopia

\begin{tabular}{|c|c|c|c|c|}
\hline Variables & Freq & $\%$ & Interview data & Document Data \\
\hline \multicolumn{5}{|l|}{ Type of policy } \\
\hline $\begin{array}{l}\text { Accommodates PPP as part of development } \\
\text { strategy }\end{array}$ & 95 & 78.51 & $\begin{array}{l}\text { Most of interviewees } \\
\text { support this option is useful } \\
\text { for Ethiopia }\end{array}$ & $\begin{array}{l}\text { Urio (2010) recommended } \\
\text { this options for developing } \\
\text { countries }\end{array}$ \\
\hline $\begin{array}{l}\text { Allows PPP as it deems necessary but not as } \\
\text { development strategy }\end{array}$ & 17 & 14.05 & ---- & \\
\hline Never allow PPP arrangement in public projects & 3 & 9 & ------- & \\
\hline \multicolumn{5}{|l|}{ Type of legal framework } \\
\hline $\begin{array}{l}\text { With specific laws, regulations and procedures } \\
\text { for PPP }\end{array}$ & 102 & 84.30 & $\begin{array}{l}\text { Most of interviewees } \\
\text { seconded this option for } \\
\text { Ethiopian legal context }\end{array}$ & $\begin{array}{l}\text { Getahun (2010) suggested } \\
\text { updating the commercial } \\
\text { code of Ethiopia }\end{array}$ \\
\hline Without specific laws and regulation for PPP & 19 & 15.70 & - & - \\
\hline \multicolumn{5}{|l|}{ Type institutional framework } \\
\hline Public agency with full mandate for PPP & 95 & 78.51 & $\begin{array}{l}\text { Some interviewees from all } \\
\text { sectors support this option }\end{array}$ & Yescombe (2007) \\
\hline $\begin{array}{l}\text { PPP units or directorates in concerned } \\
\text { public offices }\end{array}$ & 18 & 14.88 & $\begin{array}{l}\text { Some interviewees from } \\
\text { public and CSOs support this } \\
\text { option }\end{array}$ & Cheung et al. (2009) \\
\hline
\end{tabular}

Type of legal framework of PPP suggested. According to summary data presented in Table 6, 102 (84\%) stakeholders suggested the type of legal framework with specific laws, regulation, and procedures of PPP. These suggestions are also supported by most of interviewees. In the same manner, all partners from other sectors will have an opportunity to engage in PPP with confidence, good will, and sense of public accountability, knowing that the rules and regulations are functional to protect the interest of the general public as well as the participants in the partnership system. 
Type of institutional framework of PPP suggested. According to the data presented in Table 6, 95(79\%) respondents recommended that the Ethiopian government should establish an institutional framework for PPP that is led by a public agency with full mandate at federal level. This suggestion is also supported by interviewees from all sectors. The reasons mentioned by interviewees and some survey respondents through the open-ended questions are: Having a responsible and accountable public agency with full mandate to plan, promote, execute, and report issues related to PPP implementation would help to integrate capacities of all relevant sectors towards the development goals of the nation. Since the capacity of the private sector is ever increasing, the government as the most important actor and enabler of the development has to create an effective institutional mechanism to plan, prioritize, optimize, and use the growing potential of the sector in view of accelerating the general development direction of the country. Some interviewees, who also agree with notion of having a special and dedicated institution at the center, suggest another model. According to them, a special office (division, directorate, or department) could be established in the Office of the Prime Minster (Council of Ministers) to be headed by a professional appointee with the rank of minister to manage and oversee PPP related issues throughout the country. They say that the designated or appointed minster of PPP should be accountable to the Prime Minster.

In this regard, all public institutions presumably will have their own structures (PPP units or directorates) in their respective organizational structure. Heads of the PPP units or directorates may have dual accountability, to the head of the public institution and as well as to the minster of PPP in the Council of Ministers. Another option suggested by interviewees was a National Public Agency with full mandate to oversee issues related to PPP. The leadership will include representatives from the public, private, and civil society sectors. The directors' board chairperson of this special agency could be appointed by the government, because of the traditional role of the government to lead development and provide public services for its constituencies. The CEO or General Director of the special agency may be hired by open vacancy announcement from the labor market.

\section{Conclusions}

The study examined factors attracting adoption of PPP in public service delivery and development projects in Ethiopia. The study evaluated the difference in the perception of the two main players in PPP, the public and the private sectors. Hence, the three main attractive factors for implementing PPP in Ethiopia are prevalence of PPP specific legal framework, prevalence of PPP dedicated public agency, and government support in providing guarantee. In terms of the differences in perception between the public and private sector groups, the independent $t$-test results indicated that there are significant differences in three attractive factors. Regarding the perceptive difference between the respondents in the two sectors, the study concludes that the private sector in Ethiopia is ready to get involved in PPP arrangements, provided that these attractive factors are put in place by the government. It is also valid to conclude from these findings that the Ethiopian government may consider offering these three important attractive factors to motivate and engage the private sector in development oriented PPP projects. Potentially, other attractive factors, such as tax exemption, risk sharing, and loan provision may also be considered by the government to expedite engagement in PPP projects.

Respondents suggested that Ethiopia should have a policy in which PPP is considered one of the development strategies as suggested by Urio (2010). Regarding the type of legal framework, respondents suggested invariably that the country should have a PPP dedicated legal framework with specific laws, regulation, and 
procedures for PPP implementation in the development process. Stakeholders also suggested the establishment of PPP dedicated public agency with full mandate to manage and oversee issues related to PPP.

Generally, the collective suggestions imply that having a policy in which PPP is taken as a development strategy with its enabling legal environment would encourage potential sectors to collaborate with the government on mega development projects. With the establishment of a special government agency and the concomitant laws, regulations, and procedures, PPP projects could be properly executed thereby enhancing the development potential of the country.

\section{Recommendation}

The following steps or actions are recommended to be taken by the Ethiopian government and to harness the potential advantages of PPP to accelerate the ongoing development process, these are:

(1) incorporate PPP in the existing development policy as one of the development strategies for development. As a result of this, PPP should be considered as one of the pillars of the forthcoming GTP2;

(2) establish an ad hoc taskforce of experts for PPP with a special task to review the existing sectoral policies, rules, and regulations and then prepare a draft national PPP strategy;

(3) approve and announce the PPP strategy of the country. Among other points, the strategy shall explain the objectives of adopting PPP in the process of development, the expected roles of partners, the central role of the government in safeguarding or protecting the interest of the citizenry in the process of PPP operation. The basic intentions of the government in introducing PPP in the system etc.;

(4) prepare PPP specific legal framework as per the PPP strategy and conduct stakeholders' consultation on the draft legal framework. Among other points, the law should include what areas of investment are going to be open for PPP, what sort of enabling environment and incentives are devised for PPP, what modalities of PPP are preferred, applicable laws and regulation, its institutional arrangement, expected requirements for partners to initiate PPP project proposals (unsolicited projects) or to participate in open bid of PPP projects (solicited) etc.;

(5) enact the PPP specific legal framework;

(6) prepare PPP standard, procurement procedures, and model contracts;

(7) establish a federal PPP agency under the office of the Prime Minster either of the following options:

- Option 1: The current institution-Privatization and Public Enterprises Supervising Agency may be reorganized with dual mandate, keeping the current mandate and promotion, expansion, and supervising PPP projects. The new nomenclature shall focus mainly on PPP. The reorganized institution shall be empowered and made accountable to the Prime Minister's office. Head of the agency shall have a rank of a minister with proper academic and professional background related to the given mandate. There should be at least two deputy heads with a rank of state ministers. The PPP wing would be lead by one of the deputy heads and the privatization wing by another one.

- Option 2: Ethiopian Investment Agency and Ethiopian Privatization and Public Enterprises Supervising Agency may be amalgamated and reinvigorated. The new institution with a rank of ministry will have three wings - investment promotion and expansion, privatization and public enterprise supervision, and PPP promotion, implementation and expansion - to be led by deputies with state minister rank.

- Option 3: A PPP Unit could be established under MOFED to be run by a head with state minster rank that is accountable to the minister of MOFED. This unit should have a special working lateral connection with 
Ethiopian Investment Agency and Privatization and Public Enterprises Supervising Agency.

Though further study is recommended, this work provides some insight and important information for the government and the private sector concerning practical conditions for the implementation of PPP, particularly in Ethiopia. This may have provided some indications to be considered by other governments of developing countries in their endeavor to involve their respective third sector partners in development and public service delivery activities.

\section{References}

African Development Bank. (2011). Federal democratic Ethiopia country strategy. Retrieved from www.afdb.org/fileadmin/.../Ethiopia-2011-2015\%20CSP\%20ENG1.pdf

Akintoye, A., Beck, M., \& Hardcastle, C. (2003). Public private partnerships: Managing risks and opportunities. Oxford: Blackwell Science.

Alinaitwe, H., \& Robert, A. (2013). Success factors for the implementation of public private partnerships in the construction industry in Uganda. Journal of Construction in Developing Countries, 18(2), 1-14.

Binza, M. S. (2009). A public-private partnership model for the improvement of local economic development in South African metropolitan government (Ph.D. Nelson Mandela Metropolitan University).

Bringkerhoff, J. M. (2001). Partnerships are the wave of the future. American Society for Public Administration. PA Times, 24(2), $5-5$.

Cheung, E., Chan, A. P. C., \& Kajewski, S. L. (2009). Reasons for implementing public private partnership projects: Perspectives from Hong Kong, Australian, and British practitioners. Journal of Property Investment and Finance, 27(1), 81-95.

Dessalegn, R., Akalewold, B., \& Yoseph, E. (2010). CSOs/NGOs in Ethiopia partners in development and good governance (A Report Prepared for the Ad Hoc CSO/NGO Task Force, Addis Ababa).

Federal Democratic Republic of Ethiopia. (2009). Procurement and property administration proclamation. Addis Ababa: Berhanena Selam Printing Press.

Federal Democratic Republic of Ethiopia. (2009). Procurement and property administration proclamation. Retrieved from http://www.pppds.gov.et/PPPDSA/images/proclamation649.pdf

Federal Democratic Republic of Ethiopia. (2012). Investment proclamation. Retrieved from http://www.investethiopia.gov.et/images/pdf/Investment_Proclamation_No769-2012_of_Ethiopia.pdf

Getahun, S. (2010). Revisiting company law with the advent of Ethiopian commodity exchange (ECX): An overview. Mizan Law Review, 4(1), 102-141.

Hesse-Bibe, S. N. (2010). Mixed methods research: Merging theory with practice. New York: The Guilford Press.

Hodge, G. (2005). Public private partnerships and legitimacy. UNSW Law Journal, 29(3), 318-327.

Ismail, S. (2013). Factors attracting the use of public private partnership in Malaysia. Journal of Construction in Developing Countries, 18(1), 95-108.

Jamali, D. (2004). Success and failure mechanisms of public private partnerships (PPPs) in developing countries: Insights from the Lebanese context. The International Journal of Public Sector Management, 17(5), 414-430.

Li, B., Akintoye, A., Edwards, P. J., \& Hardcastle, C. (2005). Perceptions of positive and negative factors influencing the attractiveness of PPP/PFI procurement for construction projects in the UK: Findings from a questionnaire survey. Engineering, Construction and Architectural Management, 12(2), 125-148.

Ministry of Finance and Economic Development. (2006). Ethiopia: Building on progress a plan for accelerated and sustained $\begin{array}{lllll}\text { development } & \text { to } & \text { (PASDEP). } & \text { Retrieved }\end{array}$ http://www.afdb.org/fileadmin/uploads/afdb/Documents/Policy-Documents/Plan_for_Accelerated_and_Sustained_\%28PAS DEP\%29_final_July_2007_Volume_I_3.pdf

Ministry of Finance and Economic Development. (2010). Growth and transformation plan. Retrieved from http://www.ethiopians.com/Ethiopia_GTP_2015.pdf

Ministry of Information. (1994a). FDRE's policies, strategies and tactics on rural development. Retrieved from www.ethiopia.gov.et/policies-and-strategies1

Ministry of Information. (1994b). FDRE's industrial development strategy. Retrieved from www.ethiopia.gov.et/policies-and-strategies1 
Qiao, L., Wang, S. Q., Tiong, R. L. K., \& Chan, T. S. (2001). Framework for critical success factors of BOT projects in China. Journal of Project Finance, 7(1), 53-61.

Teshome, T. (2014a). Factors for implementing public-private partnership (PPP) in the development process: Stakeholders' perspective from Ethiopia. International Journal of Science and Research, 3(3), 792-799.

Teshome, T. (2014b). Public private partnership in development: Lessons in devising legal and institutional framework from South Korea. International Journal of Public Policy and Administration, 3(4), 876-896.

Tiong, R. L. K. (1996). CSFs in competitive tendering and negotiation model of BOT projects. Journal of Construction Engineering and Management, 122(3), 205-211.

Urio, P. (2010). Public-private partnerships success and failure factors for in-transition countries. Lanham: University Press of America.

Yescombe, E. R. (2007). Public private partnerships-Principles of policy and finance. London: Elsevier. 